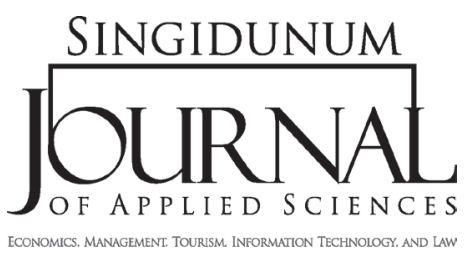

\title{
THE PROCESS OF RISK MANAGEMENT IN FINANCIAL BUSINESS.
}

\section{Danica Žigićc ${ }^{1, *}$, Miroljub Hadžić}

${ }^{1}$ Beohemija, 290 Kumodraska Street, Belgrade, Serbia

${ }^{2}$ Singidunum University, Department for Business Economics, 32 Danijelova Street, Belgrade, Serbia

\begin{abstract}
:
Risk management has become one of the most important management functions within banks and financial institutions. Its role is even more important during the current world economic crisis, with the aim of saving assets and preserving future profit. Serbian banks have recently started to introduce overall risk management function in line with Basel II agreement and take care of all sorts of risks. During recent years, a higher level of risk has been present in crisis circumstances, which means that Serbian banks have to be more careful than before. There have been clear signs of deterioration of the structure of banking assets, but hopefully, this negative trend was stopped. At the same time, one can point out that domestic banks are in better position compared to the banks in countries within the region.
\end{abstract}

\section{INTRODUCTION}

Risk management can be described as cost optimization of risk management conducted in such a way so as not to harm anyone Risk management includes business philosophy, culture and climate of the organization, as well as some business functions of financial institutions. It represents the central part of strategic management and corporate management of any commercial entity (Barjaktarović, 2009).

The focus of efficient risk management is on identifying and mitigating risk. The main objectives of risk management are, as follows:

- The ability of the business entity to survive after loss and to achieve growth and maximize profits;

- To Operate effectively in risky environments;

- To coordinate operations within the legal framework.
SINGIDUNUM JOURNAL 2012, 9 (2): 33-40

ISSN 2217-8090

UDK 005.334:336.71

Original paper/Originalni naučni rad

\section{Key words:}

risk management, banking, financial business.

Risk management is an ongoing and constantly developing process (Barjaktarović, 2009), which runs through organizational strategy and the implementation of this strategy.

Every business entity develops its own internal guidelines for risk management, which are approved and adopted by the authorities responsible for management of the economic entity.

The risk management process consists of six steps (Barjaktarović, 2009):

1. Definition of objectives - risk management program, which precisely decides what business entity expects from the program. The primary objective is to preserve operating effectiveness of the business entity. The secondary objective is to ensure the primary protection of employees from injury.

2. Risk identification - Risk manager must detect risks to which Company's business is exposed. 
Risk identification is the phase in the risk management in which, apart from the refinements of risk in the overall risk classification system and the definition of the entity, cause-effect relationships of individual risks are determined. It should be noted that risk identification is engaged in perception.

Basic classification of risk related to the operation of the business entity includes:

- a critical risk - leading to the bankruptcy of the economic entity,

- an important risk - threatening the liquidity of the business entity, but negative effects can be abstracted (either by loans of commercial banks, or by increasing the effort for the collection of overdue debts of the debtor), and

- Insignificant risk - its effects do not affect significantly operations of the entity i.e. do not threaten the liquidity and solvency of the entity.

3. Risk assessment - is the overall process of risk analysis and risk assessment. The company experts determine the potential loss and probability of loss. Gap analysis consists of risk identification, risk description and risk assessment. Risk analysis includes risk identification, risk description and evaluation of risk.

Results of risk analysis can be used for obtaining the risk profile that assesses the significance of each risk and provides a range of tools for defining priorities for the regulation of risk and makes it possible to rank each risk identified by its assigned relative importance.

Evaluation of risk is important for the decision -making process regarding the significance of risk for the business entity, and whether a certain risk should be regulated or accepted. Furthermore, it is important that the company establishes a system of internal and external risk reporting on the existence of risk.

4. Consideration of alternatives and selection of resources for risk management - it includes two solutions: risk financing and alignment of available assets included for the regulation of losses arising from risks that remain after the application of risk control techniques.

There are several methods for managing risk, as follows (Barjaktarović, 2009): methods for risk control, risk avoidance methods, risk reduction methods, risk financing methods, risk retention methods and risk transfer methods.

Having in mind the above mentioned facts, one can conclude that the basic rules for risk management are (Barjaktarović, 2009):

- Do not risk more than you can afford to lose,

- Bear in mind the randomness

- Do not risk a lot for a little.

5. Decision implementation - decision to apply administrative procedures related to the retention or transfer of risk with or without reserves, that is, formation of financial funds (reserves).

6. Evaluation and re-examination - is a constant function of risk management, which involves continuous evaluation and correction of operational risk management, given that the risk changes over time, that is, it disappears or the new one appears. Errors can also occur while managing risk and they should be corrected.

\section{IT SOLUTIONS FOR RISK ANALYSIS AND RISK CONTROL}

The software for risk management allows you: an integrated view of risk which economic entity undertakes, monitoring profitability in relation to the risk policy of the economic entity, a regulatory body reporting and measuring the risk in business. The software components for managing risk are (Barjaktarović, 2009):

- Credit risk measurement, model and simulation of exposure,

- Measuring the market risk, model and simulation of exposure,

- VaR, historical simulation, Monte Carlo simulation,

- „Greek“calculators of risk (beta, delta, gama, etc.),

- Modeling and scenario generation,

- Test of extreme events.

A well-known software solution for worldwide risk management is GRC - Governance Risk Controls, which completely covers the main stage in risk management.

If we consider the banking practice in Serbia, IT solutions for risk management are more developed in banks where the foreign capital prevails. Such banks usually use a group of software solutions and models, the outsource software solutions. In the case of less developed local banks, risk management comes down to the use of Excel. 


\section{NEW REQUIREMENTS FOR BANKING BUSINESS}

Bank performances in the global market are becoming increasingly risky, suggesting a need for the well-developed risk management. Risk is immanent in the banking business and it represents the accompanying consequence of market forces. Such increasing risk is related to the process of globalization of the banking business.

An audit function of banks is organized to secure that the banks pay their obligations and to originally make a set of rules banks are required to adhere to their business. Those rules reflect the obligation of banks that they have to hold a certain amount of assets as fully liquid.

In addition, there is a rule in line with Basel I agreement that the bank has to fulfill a minimum capital reserve requirement to its risk assets.

This disparity has proved to be an acute problem when the banks of Japan began with very aggressive lending activities in the international market without taking into account the amount of their capital. Banks in other developed countries have considered this competition as destructive and dangerous, so they launched the initiative to establish international norms and standards related to the obligation of banks to provide an adequate amount of capital assets at risk.

After a series of banking crisis including the bankruptcy of Herstatt Bank in Germany, central banks and supervisory authorities of the developed countries (USA, Canada, UK, France, Germany, Italy, the Netherlands, Luxembourg, Belgium, Switzerland, Japan), founded the Basel Committee on banking supervision in 1975 (It is a committee of officials from central banks and supervisors who meet every three months at the Bank for International Settlements in Basel.). In order to ensure equality of Member States in assessing the adequate risks assumed capital, the Basel Control Committee published The Basel Agreement I in 1988. Under this Agreement, the banks with international operations in countries of "the Group of 10 " were obliged to have their own capital of at least $8 \%$ of assets. This is a minimum, and national regulatory bodies have the right to establish higher levels of capital adequacy.

Volatility of financial markets and their dynamic development have emphasized the need for more sophisticated risk measurement approaches over the past ten years.
Banking risks as a whole, and therefore credit risks, have become more complex, and some large and internationally active banks have developed their own methods for risk management.

The proposal of the new Basel Agreement, the Basel Agreement II, was released in early 2001. Conceived on the idea to increase the sensitivity of the guiding financial institutions at risk, the new agreement provides a more complex approach to determining minimum capital requirements in view:

- More comprehensive treatment of risk;

- More sophisticated instruments for risk measurement in light of a number of methods for measuring risk;

- More incentives for banks to improve their internal risk measurement methods;

- More significant and broader roles of national supervisory institutions in terms of intensifying the dialogue with the banks in the development of internal risk assessment methods and controls required;

- Higher transparency of financial institutions as an essential prerequisite for the improved financial discipline.

The main objective of Basel Agreement II is to increase the sensitivity to risk, that is, to correlate the height of the required capital with the amount of risk.

\section{STRATEGIC MANAGEMENT OF BANKING RISK}

The bank should have the ability to review the likelihood that risk event does not modify or affect the operations of the bank and its consequences if it happens. The bank is obliged to establish an organization, human resources and sufficient reserve funds in order to cope with the risk successfully.

The function of the Risk management sector is to maintain risk within the adequate action framework and it is essential to provide:

- Reliable information and accurate reports about the treats, the occurrence or the effect of risk;

- Measuring the effects of risk in cash equivalents - expressed through the reduction of bank wages or through damages applied to the bank assets;

- Appropriate strategies, plans and programs to prevent and combat the effects of each risk 
by employing the appropriate business policies, procedures and standards.

Experience in banking business shows that the common shortcomings in risk management of the bank are as follows: too aggressive activity of the Board of directors, disunited or inattentive board of directors, the negative impact of insiders or management, the risk management sector dependence on the Executive Board and more.

\section{OPERATIONALIZATION OF RISK MANAGEMENT IN SERBIAN BANKING SECTOR}

A complete risk management system is set up by the Law on Banks, which defines the basics of the system - the risk, the authorities and their responsibilities, the type of risk management procedures demanding that the bank itself defines and constitutes everything else in this legal framework.

The Banking Act (the Law on Banks) also requires that the bank should have an adequate IT system (software support), the system of internal control and treasury operations system. Accordingly, these three sub-systems should be set up to perform their functions separately from the business functions and separately for the purposes of risk management.

The Bank is obliged to identify, to measure and assess the risks to which it is exposed in its operations and to manage those risks. The bank is also obliged to establish an organizational unit - sector - responsible merely for risk management. Risk management is influenced by the size and organizational structure of the bank, its business strategy, the scope of activities and types of operations performed. The Bank prescribes, in its own regulations, procedures for the identification, measurement and assessment, as well as risk management (Hadžić, 2009).

Standards and activities that exceed the level lines of business are in the focus of the corporate function. Consequently, it enables the decisionmaking process based on the adequate risk analysis and trends at the bank, which through using the data from external databases enable the exchange of experience and best practices and determine the size of the limits. These are the basis for calculating capital costs and consolidated reporting to the top management.
Contemporary models of risk management at the bank rely on the management structure presented. It is about the control flow between two levels (Barjaktarović, 2009):

- top-down - from management to employees - the direct perpetrators of transactions,

- down-top feedback from employees to the top management of the bank.

Hereby, the whole management structure of the bank is involved in the daily decision-making, which is something required by the very nature of risks the bank is exposed to.

\section{THE CASE: RISK MANAGEMENT OF KOMERCIJALNA BANKA A.D., BELGRADE}

The world economic crisis started to influence negatively Serbian economy at the end of 2008 . The banking sector in Serbia was developing fast in the period prior to crisis and was in somewhat better shape compared to other transition economies within the region. Capital adequacy of Serbian banks was $28 \%$ and credit recovery was more than $90 \%$ on average. In order to ease monetary policy, National bank of Serbia introduced a set of measures together with the Government. Firstly, liquid position of the whole banking sector was improved. Secondly, NBS concluded the so - called Vienna agreement with banks with the prevailing foreign capital, by which Serbian exposure would stay as it was before crisis. Thirdly, the set of legal changes was enacted in order to secure foreign exchange deposits (the guaranteed amount of deposits was put from 3 thousands up to 50 thousands Euro) and the tax duties related to capital gains from deposits were annulled. Fourthly, the Government introduced incentives by which interest rate was subsidized for credit lines, for companies for liquid assets, for investments in non fixed assets and for citizens. Fifthly, the Stand - By agreement with IMF supported RSD stability (2.7 billion Euros and 1.1 billion Euros, the current arrangement).

Worsening economic conditions in Serbian banking sector led to slowing growth and in 2011 to stagnation. Number of employees within the banking sector decreased from 31.3 thousand and stabilized at 29.9 thousands employees. After a modest increase in assets, crediting and capital in 2010, during the first half of 2011,the total assets decreased by $2 \%$, credit volume decreased by $2 \%$ in nominal 
terms, while capital increased by $4 \%$. The structure of new credit lines got somewhat worsened, as banks placed financial sources mainly to the state and public companies. Credit lines in default (more than 90 days) increased to $19 \%$ (from $17 \%$ in 2010). The Capital adequacy decreased in the mid of 2011 and stabilized at $20 \%$. Profitability increased compared to the same period in 2010 and total profit of Serbian banks amounted to 178 million Euros. There were signals of modest economic recovery at the end of 2009 and in 2010 (GDP increased 1\% in 2010 , Staistical office RS), but the fears of repeat recession are present from the second quarter of 2011.

Komercijalna Banka has announced the results achieved in the first nine months of 2011, showing a continuing trend of growth in profitability of the banking institution.

Komercijalna Banka has announced pre-tax profit of just under 3 billion, an increase of about 50 percent compared to the same period last year. The largest bank that operates under government control has increased the efficiency, especially in the main business area. Interest income amounted to 13.3 billion (growth of 18.2 per cent), while fee and commission income amounted to 3.7 billion (growth of 15.6 per cent). The total income from these items amounted to 10.4 billion RSD and was 29.4 percent higher compared to the first three quarters of 2010.

Total assets of banks at end of September amounted to 258.8 billion, which represents an increase of $1.1 \%$ from the beginning of the year There were no major dramatic shifts in the balance sheet items, and positions in loans and deposits were insignificantly lower than in the first nine months last year and amounted to 148.8 billion dinars.

Komercijalna Banka, Belgrade realized profit from operations in the first quarter of 2011 amounting to 895.129 RSD. In the same period last year it achieved a higher operating profit in the business for 269.813 RSD. Relying on this we can conclude that the business was more successful in the current than in the past year.

Total assets in 2011 (up to 30th September) increased by $1.14 \%$ compared to the previous year amounting to 258.805 thousand RSD, and by $26.08 \%$ compared to the year 2009. In 2009, the given loans and deposits amounted to
115.106 million RSD, and in 2010 recorded an increase amounting to 150.566 million RSD. Slight decrease was recorded in 2011 amounting to 148.774 million RSD.

The total assets within the Balance sheet in 2010. grew up to 50.611 million RSD or $24.7 \%$ compared to the previous year. The Loans and advances increased by 35.460 million RSD, or $30.8 \%$. As of $31^{\text {st }}$ December 2010, the total loans and advances (economy, population, and banks and financial hubs or organizations) amounted to 150.566 million RSD, representing $58.8 \%$ of the total Balance sheet assets.

In 2010. the position of the cash and cash equivalents decreased by $24.3 \%$, due to the revised regulations on mandatory reserves of the NBS. The most significant increase recorded in the previous year was related to investment in securities. Finally, the total amount of funds placed in a risk-free government securities amounted to 18 billion RSD. In 2010, the planned capital increase carried out in subsidiaries amounted to EUR 30 million. Namely, it was placed into Commercial Bank, Budva, Monetenegro 10 million and Commercial Bank, Banja Luka, Republika Srpska 20 million EUR. In the structure of assets, we note that the cash and cash equivalents recorded a decline in 2011 compared to 2010 by $20.08 \%$, and by as much as $39.52 \%$ compared to 2009. In 2011, the callable deposits and loans recorded an increase of $17.12 \%$ compared to the 2010 , and $9.5 \%$ compared to 2009 . The claims for interest, fees, changes in fair value of derivatives and other receivables increased by $18.9 \%$ compared to 2011 and 2011 increased by $50.4 \%$ compared to 2009 and 2011.

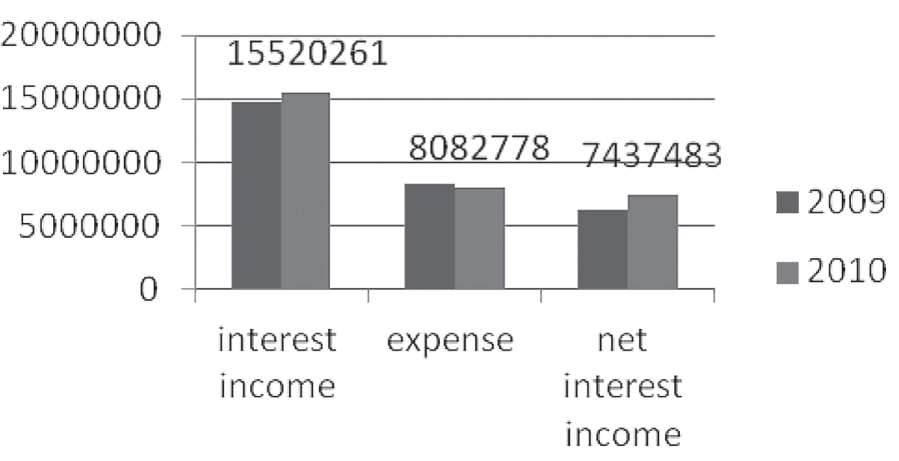

Figure 1. A comparison between interest income, expense and net interest income during 2009-2010. 


\begin{tabular}{lcc}
\hline & 2009 & 2010 \\
\hline Interest income & 14.713 .932 & 15.520 .261 \\
\hline Interest expense & 8.379 .834 & 8.082 .778 \\
\hline Net interest income & 6.334 .099 & 7.437 .483
\end{tabular}

Table 1. Data related to, expense and net interest income during 2009-2010.

The net interest income of the Bank in 2010 amounted to 7.437 million RSD, representing an increase of $17.4 \%$ compared to the previous year. The revenues have been increasing interest for 806.3 million RSD, or 5.5\%, while the expenses on deposit rates fell by 297.1 million RSD, or by $3.5 \%$. Reducing expenditure on a new deposit rates has been achieved as a result of collecting deposits under more favorable market conditions, despite the growth in deposits. In 2010, the Bank carried out optimization of the structure of deposits from the standpoint of price and maturity. In the structure of interest income, the largest share has revenue from loan interest for enterprises (8.073 million RSD, or $53.0 \%$ ), while the total interest expenditures refer to the largest share of deposit interest for citizens (5.298 million RSD or 65.6\%), which for the most part relates to foreign currency savings deposits of citizens.

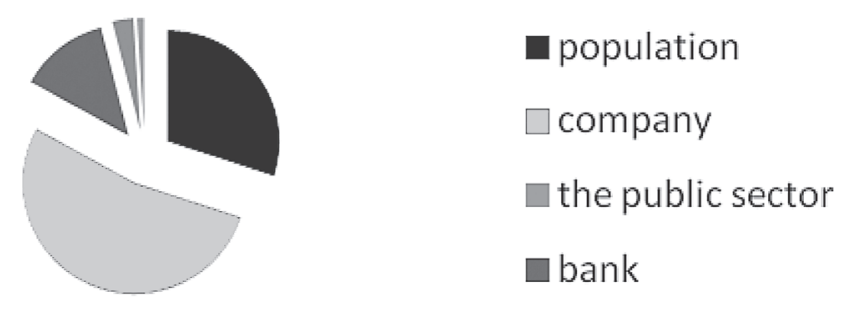

Figure 2. Interest income for 2010 by sector

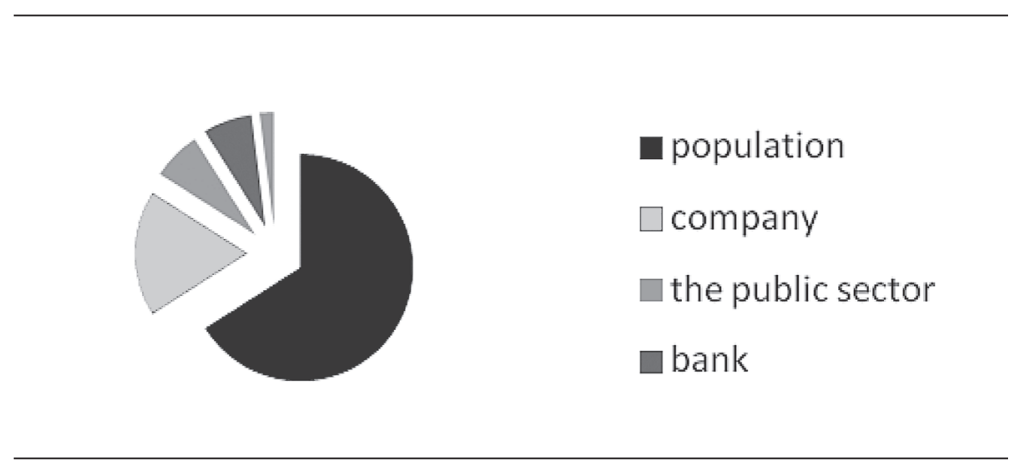

Figure 3. Interest expanse by sector in 2010.

When analyzing investments we used Cover ratio, which is equal to the ratio correction value and gross investments. We calculate the three dates:

- September 12, 2011 -was 8.61\%

- October 12, 2011 -amounted to 7.49\%

- November 9,2011- amounted to 7.38\%

Impaired loans amounted to 142.695.379 (in thousands) in 2010 and recorded an increase compared to 2009 when they amounted to 85546.197 (in thousands). Impaired loans are related to bad loans, which are rated with 4 and 5 ratings.
In contrast to the observation of the auditor's report on the Structure of assets, we can note that in 2010 a drop in loans which are not impaired was recorded, compared to 2009.

If we compare the Coverage Ratio Commercial Bank with an average in the branch and the branch leader (Banca Intesa), the industry average is $8.5 \%$ and Intesa has $6.9 \%$ Coverage Ratio as of September 30,2011 . This shows that the structure of assets is better than limit but less than the branch leaders. It is important to note that the bank estimates using different methodologies. 


\begin{tabular}{llrrr}
\hline \multicolumn{1}{c}{ ASSETS } & 31 September. 2011. & \multicolumn{1}{c}{2010.} & \multicolumn{1}{c}{2009.} \\
\hline \multicolumn{1}{c}{2} & \multicolumn{1}{c}{4} & \multicolumn{1}{c}{5} \\
\hline 1. & Cash and cash equivalents & 16.562 .088 & 20.724 .645 & 27.387 .157 \\
\hline 2. & Callable deposits and loans & 51.086 .075 & 43.615 .232$. & \multicolumn{1}{c}{$46,651,225$} \\
\hline 3. & Interest, fees and sale of loans and deposits & 1.408 .716 & 1.185 .242 & 936.866 \\
\hline 4. & Loans and advances & 148.774 .729 & 150.566 .311 & 115.106 .246 \\
\hline 5. & Securities (excluding treasury) & 21.301 .395 & 18.267 .497 & 566.509 \\
\hline 6. & Shares & 5.788 .066 & 5.286 .005 & 2.703 .423 \\
\hline 7. & Other placements & 2.079 .983 & 2.308 .011 & 2.272 .876 \\
\hline 8. & Intangible assets & 505.780 & 467.547 & 326.526 \\
\hline 9. & Fixed assets and investment property & 7.529 .878 & 6.820 .704 & 7.057 .487 \\
\hline 10. & Assets held for sale & 101.040 & 735.432 & 104.898 \\
\hline 11. & Deferred tax assets & 48.903 & 0 & 109.217 \\
\hline 12. & Other assets & 3.619 .168 & 5.351 .683 & 2.034 .792 \\
\hline & TOTAL ASSETS & 258.805 .821 & 255.868 .309 & 205.257 .221 \\
\hline
\end{tabular}

Table 2. Balance sheet, Komercijalna banka ad, Belgrade

Komercijalna banka achieved in 2011 a net profit of 3.5 billion which is 39.4 percent higher than a year before, the data from the unaudited financial statements for the previous financial year. The main business of the bank has greatly contributed to the increase in profitability: profit from interest increased by 32.5 percent to $\$ 9.9$ billion, while income from fees and commissions rose by 13.6 percent to 4.4 bilion.

The main business of the bank has greatly contributed to the increased profitability: profit from interest increased by 32.5 percent to $\$ 9.9$ billion, while income from fees and commissions rose by 13.6 percent from 2010 to 1.3 billion dinars last year.

A major contribution to a good end result of the bank comes from small negative exchange rate differences, resulting from enormous expenditures in 2010 in the amount of 7.4 billion.

Assets of commercial banks on the last day in 2011 amounted to 275.5 billion representing a growth of 7.7 percent since the beginning of the year.

The budget for 2012 which provides for the recapitalization of commercialization of commercial banks amounted to 11.572 billion.

There is a deadline by which the state should show the intent in terms of the ownership of the bank. So far, however, there have been no intentions concerning its sale.
If the state does not exercise the right of the recapitalization, the financial institutions would have a 51.64 percent stake. With this recapitalization, bank reserves and strengthens its leading position.

The Bank's second-largest balance sheet total amounts to 259 billion dinars, which makes 10.2 percent of the market share. Komercijalna Banka is among the top five regarding the amount of profit before tax.

When it comes to the dilemma of whether the state should have a majority share in the banks, there are a lot of controversies.

"In general, in good times, the state should withdraw from the banking system and should not constitute unfair competition to private banks. However, in adverse conditions, private banks often show no understanding for the needs of the economy and reduce their lending activity. It should be noted, that our experience with state banks was quite bad, where most of them went bankrupt, "says economist Fabris (2012).

\section{CONCLUSIONS}

Risk management function has become the most important management function in recent years. Its importance is especially evident within worsening conditions for financial business as a result of the current economic crisis. The primary objective 
of risk management is to preserve assets of the financial institution and secure the projected profit. Nowadays, international authorities and national regulatory institutions have started introducing high level requirements related to risk management in the banking sector. Banks themselves have developed a wide range of instruments in order to improve the analysis and cope more efficiently with increasing risks. During the current economic crisis, Serbian banks face slowing growth and stagnation of overall activities, as well as worsening performances and increasing risks. Komercijalna Banka a.d, Belgrade successfully copes with those problems and due to its adequate risk management organization and process it has improved its efficiency and position on the domestic market.

\section{REFERENCES}

Barjaktarović, L. (2009) Upravljanje rizikom. Belgrade: Singidunum University. (in Serbian)

Cronhy, M., Galai, D., Mark, R. (2001) Risk Management. New York; London: McGraw-Hill.

Cvetinović, M. (2008) Upravljanje rizicima u finansijskom poslovanju. Belgrade: Singidunum University. (in Serbian)

Fabris, N. (2012) Država dokapitulizuje Komercijalnu banku sa 11 milijardi dinara. Gde investirati [online]. Available from: http://www.gdeinvestirati.com/ banke/vesti/6630-drzava-dokapitalizuje-komercijalnu-banku-sa-11-mld-dinara [accessed 2 June 2012]. (in Serbian)

Frenkel, M., Hommel, U., Rudolf, M. (2005) Risk management: challenge and opportunity. 2 nd. ed. Berlin: Springer.
Guiso, L., Paiella, M. (2003) Risk Aversion Wealth and Background Risk. Journal of the European Economic Association. 6 (6), 1109-1150.

Hadžić, M. (2009) Bankarstvo. Belgrade: Singidunum University. (in Serbian)

Krstić, B., Marinković, S. (1998) Finansijski rizici u bankarstvu. Jugoslovensko bankarstvo. 27 (5/6), 3-11. (in Serbian)

Kupper, E.F. (1999) Risk management in Banking [online]. Available from: http://www.ppge.ufrgs.br/giacomo/arquivos/esp207/kupper-1999.pdf [accessed 6 June 2012].

Scheck, G. (2002) Risk Management and Value Creation in Financial Institution. New York; Chichester: Wiley.

Stephanou, C., Mendoza, J.C. (2005) Credit Risk management Under Basel II: An Overview and Implementation issues for Developing Countries. World Bank Policy Research Working Paper 3556 [online]. Available from: http://www-wds.worldbank.org/servlet/ WDSContentServer/WDSP/IB/2006/01/10/00011274 2_20060110171251/Rendered/PDF/wps35560corrected.pdf [accessed 25 August 2012].

Van Greuning, H., Brajović-Bratanović, S. (2003) Analyzing and managing Banking Risk. 2nd ed. Washington, D.C.: World Bank.

Van Greuning, H., Brajović-Bratanović, S. (2006) Analiza i upravljanje bankovnim rizicima: pristupi za ocjenu organizacije upravljanja rizicima i izloženosti financijskom riziku. 2. izd. Zagreb: Mate. (in Croatian)

Vunjak, N. (2005) Finansijski menadžment: Poslovne finansije. Bečej: Proleter; Subotica: Faculty of Economics, University of Novi Sad; Podgorica: Unireks. (in Serbian)

\section{PROCES UPRAVLJANJA RIZIKOM U FINANSIJSKOM POSLOVANJU}

\section{Rezime:}

Upravljanje rizikom je postala jedna od najvažnijih upravljačkih funkcija u bankama i finansijskim institucijama. Njena uloga je još izraženija tokom trajanja ekonomske krize i ima za cilj da se sačuvaju sredstva i budući profit. Banke u Srbiji su nedavno počele da uvode opštu upravljačku funkciju koja je u skladu sa Basel II sporazumom kao i da vode računa o različitim vrstama rizika.Tokom proteklih godina zabeležen je sve veći nivo rizika u kriznim situacijama, što predstavlja upozorenje za banke u Srbiji da budu dosta opreznije. Postojali su jasni znaci koji ukazuju na pogoršanje strukture bankovnih sredstava, ali je na svu sreću ovaj negativni trend zaustavljen. $U$ isto vreme, možemo istaći da se domaće banke nalaze u boljem položaju u odnosu na banke u zemljama u regionu.

\section{Ključne reči:}

upravljanje rizikom,

bankarstvo,

finansijsko poslovanje. 